\title{
Differential Probability Functions for Investigating Long-term Changes in Local and Regional Air Pollution Sources
}

\author{
Mauro Masiol ${ }^{*}$, Stefania Squizzato ${ }^{1}$, Meng-Dawn Cheng ${ }^{2}$, David Q. Rich ${ }^{1,3,4}$, \\ Philip K. Hopke ${ }^{1,5^{*}}$ \\ ${ }^{1}$ Department of Public Health Sciences, University of Rochester Medical Center, Rochester, NY 14642, USA \\ ${ }^{2}$ Environmental Sciences Division, Oak Ridge National Laboratory, Oak Ridge, TN 37831, USA \\ ${ }^{3}$ Department of Environmental Medicine, University of Rochester Medical Center, Rochester, NY 14642 USA \\ ${ }^{4}$ Department of Medicine, University of Rochester Medical Center, Rochester, NY 14642, USA \\ ${ }^{5}$ Center for Air Resources Engineering and Science, Clarkson University, Potsdam, NY 13699, USA
}

\begin{abstract}
Conditional probability functions are commonly used for source identification purposes in air pollution studies. CBPF (conditional bivariate probability function) categorizes the probability of high concentrations being observed at a location by wind direction/speed and investigate the directionality of local sources. PSCF (potential source contribution function), a trajectory-ensemble method, identifies the source regions most likely to be associated with high measured concentrations. However, these techniques do not allow the direct identification of areas where changes in emissions have occurred. This study presents an extension of conditional probability methods in which the differences between conditional probability values for temporally different sets of data can be used to explore changes in emissions from source locations. The differential CBPF and differential PSCF were tested using a long-term series of air quality data (12 years; 2005/2016) collected in Rochester, NY. The probability functions were computed for each of 4 periods that represent known changes in emissions. Correlation analyses were also performed on the results to find pollutants undergoing similar changes in local and regional sources. The differential probability functions permitted the identification of major changes in local and regional emission location. In Rochester, changes in local air pollution were related to the shutdown of a large coal power plant $\left(\mathrm{SO}_{2}\right)$ and to the abatement measures applied to road and off-road traffic (primary pollutants). The concurrent effects of these changes in local emissions were also linked to reduced concentrations of nucleation mode particles. Changes in regional source areas were related to the decreases in secondary inorganic aerosol and organic carbon. The differential probabilities for sulfate, nitrate, and organic aerosol were consistent with differences in the available National Emission Inventory annual emission values. Changes in the source areas of black carbon and $\mathrm{PM}_{2.5}$ mass concentrations were highly correlated.
\end{abstract}

Keywords: Differential probability functions; Long-term trends; Air pollution.

\section{INTRODUCTION}

Air pollution is decreasing in many developed countries (Colette et al., 2011; Guerreiro et al., 2014; Ahmed et al., 2015; Masiol et al., 2017a), including the United States (Parrish et al., 2011; Pouliot et al., 2015; Duncan et al., 2016; Nopmongcol et al., 2016; Emami et al., 2018; Masiol et al., 2018; Squizzato et al., 2018). Downward trends reflect the implementation of legislation and regulations (Gerard and Lave, 2005; Parrish et al., 2011), the application

\footnotetext{
* Corresponding authors. E-mail address: phopke@clarkson.edu (P.K. Hopke); mauro.masiol@gmail.com (M. Masiol)
}

of increasingly stringent emissions standards, improved abatement technologies, changes in fuel sulfur content (Klimont et al., 2013; Kheirbek et al., 2014), road (Dallmann and Harley, 2010; Russell et al., 2012; U.S. EPA, 2016) and off-road (Eyring et al., 2010; IMO, 2013; Masiol and Harrison, 2014; U.S. EPA, 2016; Zetterdahl et al., 2016) fuels, economic drivers (Tong et al., 2016), and energy policy. Over the past decades, those measures took place at different scales across the U.S., from local, city, and metropolitan area to state, regional, and even continental scales. Recently, Emami et al. (2018) and Masiol et al. (2018) have reported the changes in air pollution concentrations measured in Rochester, NY, a moderate sized city typical of the northeastern United States. A major research challenge is to determine if the trends represent positive/negative feedbacks of specific mitigation measures or the synergy 
of implementation of multiple policies at different scales rather than the consequence of changes in human habits, a reflection of recent economic conditions, and/or the direct/indirect effects of climate change.

Many methods are used to investigate the location or direction of emission sources relative to the sampling location(s). These methods include nonparametric wind regression (NWR) (Henry et al., 2002; Kim and Hopke, 2004; Yu et al., 2004), polar plots (Carslaw et al., 2006; Carslaw and Beevers, 2013; Grange et al., 2016), polar plots with background subtraction (Carslaw et al., 2006; Masiol and Harrison, 2015), conditional probability function (CPF) (Kim et al., 2003; Kim and Hopke, 2004; Penkey et al., 2006), and conditional bivariate probability function (CBPF) (Uria-Tellaetxe and Carslaw, 2014). Long-range transported pollutants are evaluated with trajectory ensemble methods based on back-trajectories, including clustering (Harris and Kahl, 1990; Brankov et al., 1998; Cape et al., 2000; Abdalmogith and Harrison, 2005; Squizzato et al., 2012), potential source contribution function (PSCF) (Ashbaugh et al., 1985; Malm et al., 1986; Polissar et al., 2001; Poirot et al., 2001; Penkey et al., 2006), concentration field analysis (CFA) (Seibert et al., 1994), residence time weighted concentration (RTWC) (Stohl et al., 1996; Zhou et al., 2004), quantitative transport bias analysis (QTBA) (Keeler, 1987), simplified QTBA (SQTBA) (Zhou et al., 2004), and concentration weighted trajectory (CWT) (Hsu et al., 2003; Zhou et al., 2004). Such methods extensively reviewed and tested elsewhere (Lupu and Maenhaut, 2002; Hsu et al., 2003; Zhou et al., 2004; Penkey et al., 2006; Kabashnikov et al., 2011; Fleming et al., 2012; Brereton and Johnson, 2012; Squizzato and Masiol, 2015; Hopke, 2016). However, these techniques do not identify areas where emission changes have occurred.

This study presents an extension of conditional probability methods helpful in the investigation of long-term series of air quality data. The differences between conditional probability values for temporally different data sets were used to explore changes in local and regional air pollution sources. CBPF (conditional bivariate probability function) categorizes the probability of high concentrations ( $>$ threshold criterion) being observed at a location by wind direction/speed and aims to investigate the directionality of local sources. PSCF (potential source contribution function), a trajectoryensemble method, allows the identification of the source regions most likely to be associated with high measured concentrations ( $>$ threshold criterion). Its utility has been previously examined by Cheng and Lin (2001) and Begum et al. (2005). The differential CBPF and differential PSCF were tested using a long-term series of air quality data (12 years; 2005/2016) collected in Rochester, NY, a typical medium-sized metropolitan area in northeastern United States. Negative differential probabilities highlight areas where emissions are decreased. Conversely, positive differential probabilities point out areas where emissions have increased. Probability functions were computed over 4 multiple year periods that represent known changes in emissions.

\section{MATERIALS AND METHODS}

\section{Data Sources, Handling, and Consistency}

Air quality data used in this study were collected at the NYS Department of Environmental Conservation reference site for Rochester (Fig. S1). The site is representative of citywide air quality, but also lies $\sim 300 \mathrm{~m}$ from the intersection of two major highways (I-490 and I-590) with an average traffic of $\sim 230,000$ vehicles day ${ }^{-1}$.

Hourly $\mathrm{CO}, \mathrm{NO}$, total reactive nitrogen $\left(\mathrm{NO}_{\mathrm{y}}\right), \mathrm{SO}_{2}, \mathrm{O}_{3}$, and $\mathrm{PM}_{2.5}$ concentrations were routinely measured in accordance with federally mandated methods. $\mathrm{NO}_{2}$ was estimated as $\mathrm{NO}_{\mathrm{y}}-\mathrm{NO}$. Equivalent black carbon (BC) (Petzold et al., 2013) and Delta-C (DC, difference between absorbance at 370 and $880 \mathrm{~nm}$ used to estimate biomass burning PM) (Sandradewi et al., 2008; Wang et al., 2011a), were measured using aethalometers with $\mathrm{PM}_{2.5}$ cut-off cyclones (Table S1). Twenty-four hour integrated $\mathrm{PM}_{2.5}$ species data were retrieved from the U.S. EPA chemical speciation network, including elemental (EC) and organic (OC) carbon, nitrate, sulfate, ammonium, and $\mathrm{K}^{+}$(Solomon et al., 2014). Data were processed to return a consistent dataset over the 2005-2016 period. Details are reported in supplementary materials. Since secondary material needs to be estimated to account for local and regional sources (Wang et al., 2012a; Masiol et al., 2017b), OC was also split between primary $\left(\mathrm{OC}_{\mathrm{pri}}\right)$ and secondary $\left(\mathrm{OC}_{\mathrm{sec}}\right)$ using the EC tracer method (Turpin and Huntzicker, 1995; Lim and Turpin, 2002; Cabada et al., 2004). Details are provided in the supplementary materials.

Particle number concentrations (PNCs) from 11 to $470 \mathrm{~nm}$ were measured with a scanning mobility particle spectrometer (SMPS). Details are reported elsewhere (Jeong et al., 2004; Masiol et al., 2018). SMPS spectra were split into 3 ranges roughly representative of nucleation $(11-50 \mathrm{~nm}$; $\left.\mathrm{PNC}_{11-50}\right)$, Aitken nuclei $\left(50-100 \mathrm{~nm} ; \mathrm{PNC}_{50-100}\right)$ and accumulation (100-470 nm; $\mathrm{PNC}_{100-500}$ ) particles.

\section{Meteorological Data}

Wind data from the Greater Rochester International Airport (KROC) were retrieved from the NOAA NCDC repository (https://www.ncdc.noaa.gov/data-access). Backtrajectories were calculated using the NOAA/ARL Hybrid Single-Particle Lagrangian Integrated Trajectory (HYSPLIT_4) model (Stein et al., 2015; Rolph et al., 2017), using the NCEP/NCAR Reanalysis data (Kalnay et al., 1996). HYSPLIT was run backward in time for $120 \mathrm{~h}$ using the vertical mixing model with a starting height of $500 \mathrm{~m}$ a.g.l. (Cheng et al., 1993) and 1-h intervals (24 trajectories per day).

\section{Overview of Probability Functions}

Conditional probability functions (CPF, CBPF, and PSCF) are widely used to locate the potential local and external sources affecting a site. CPF assesses the probability of wind directions associated with specific threshold criteria (usually the $75^{\text {th }}-90^{\text {th }}$ percentiles). CPF was further extended to the bivariate case to produce a conditional bivariate probability function (CBPF) plot using wind speed 
as a third variable plotted on the radial axis (Uria-Tellaetxe and Carslaw, 2014):

$$
C B P F_{\Delta \theta, \Delta v}=\frac{m_{\Delta \theta, \Delta v} \mid[x] \geq C}{n_{\Delta \theta, \Delta v}}
$$

where $m_{\Delta \theta, \Delta v}$ and $n_{\Delta \theta, \Delta v}$ are respectively the occurrence of observations exceeding the threshold $C$ and the total number of data in the wind sector $\Delta \theta$ and wind speed interval $\Delta v$.

For distant sources, PSCF identifies the potential source regions located within a grid cell at latitude $i$ and longitude $j$ with probabilities of exceeding a threshold criterion:

$$
\operatorname{PSCF}_{i, j}=\frac{m_{i, j} \mid[x] \geq C}{n_{i, j}}
$$

where $n_{i, j}$ represents the number of times the trajectory endpoints fell into cell $i, j$ in the domain grid, and $m_{i, j}$ is the number of times the observed concentration exceeds the threshold $C$.

In this study, differential CBPF and PSCF functions are defined as the difference between the probabilities estimated in each of the two different periods $\tau_{1}$ and $\tau_{2}$, with $\Delta \tau=\tau_{2}-$ $\tau_{2}$ :

$$
\begin{gathered}
\Delta C B P F_{\Delta \theta, \Delta v, \Delta \tau}=\frac{m_{\Delta \theta, \Delta v, \tau 2} \mid\left[x_{\tau 2}\right] \geq C_{\beta \tau 2}}{n_{\Delta \theta, \Delta v, \tau 2}} \\
-\frac{m_{\Delta \theta, \Delta v, \tau 1} \mid\left[x_{\tau 1}\right] \geq C_{\tau 1}}{n_{\Delta \theta, \Delta v, \tau 1}} \\
\Delta P S C F_{i, j, \Delta \tau}=\frac{m_{i, j, \tau 2} \mid\left[x_{\tau 2}\right] \geq C_{\tau 2}}{n_{i, j, \tau 2}}-\frac{m_{i, j, \tau 1} \mid\left[x_{\tau 1}\right] \geq C_{\tau 1}}{n_{i, j, \tau 1}}
\end{gathered}
$$

A single criterion $C\left(75^{\text {th }}\right.$ percentile $)$ was calculated over the whole period (2005-2016), and was then applied to single periods, i.e., $C \tau_{1}=C \tau_{2}$. The criterion, $C$, values used for each variable (and relative concentrations) are listed in Table S2. Wind speed/direction data and back-trajectories have 1-h time resolution and are matched with the concentration of hourly-measured variables (gases, $\mathrm{PM}_{2.5}$, $\mathrm{BC}$, and Delta-C). However, PM compositional data are available for integrated 24-hour samples. Each value is matched with the 24 wind values or for the 24 trajectories that were calculated for each day (Kim and Hopke, 2004).

PSCF values may be affected by grid cells containing only a few endpoints that may be overestimated. Multiple weighting functions, $W_{i, j}$, have been proposed to avoid this issue (Polissar et al., 2001; Begum et al., 2005; Kim and Hopke, 2006). The weighting function used here was:

$$
W\left(n_{i, j}\right)=\left\{\begin{array}{cc}
p_{c}=p & n_{i, j}>2 \cdot \bar{N} \\
p_{c}=p \cdot 0.75 & \bar{N}<n_{i, j} \leq 2 \cdot \bar{N} \\
p_{c}=p \cdot 0.5 & \bar{N} / 2<n_{i, j} \leq \bar{N} \\
p_{c}=p \cdot 0.15 & n_{i, j} \leq \bar{N} / 2
\end{array}\right.
$$

where $p_{c}$ is the probability corrected for the function $W\left(n_{i, j}\right), p$ is the probability value from the uncorrected function, and $\bar{N}$ is the average number of endpoints over the grid cells with at least one endpoint. Since single PSCFs are weighted, $\triangle P S C F_{i, j, \Delta \tau}$ was not weighted further. However, the PSCF values were computed only for cells having with more than 100 endpoints. The PSCF analyses were made for grid cells of $1^{\circ}$ latitude by $1^{\circ}$ longitude.

In a similar way, $\mathrm{CBPF}$ probability is less reliable for small numbers of observations $\left(n_{\Delta \theta, \Delta v}\right)$. A weighting function was applied:

$$
W\left(n_{\Delta \theta, \Delta v}\right)=\left\{\begin{array}{cc}
p_{c}=p & n_{\Delta \theta, \Delta v}>4 \\
p_{c}=p \cdot 0.75 & n_{\Delta \theta, \Delta v}=4 \\
p_{c}=p \cdot 0.5 & n_{\Delta \theta, \Delta v}<4
\end{array}\right.
$$

The CBPF analyses were made using a sector size $\Delta \theta$ of $10^{\circ}$ and wind speed increments, $\Delta v$, of $1 \mathrm{~m} \mathrm{~s}^{-1}$. The major issue in the computation of CBPF values is the choice of the best wind speed/wind direction bins (the choice of $\Delta \theta, \Delta v$ intervals is arbitrary). The "original" CBPF approach proposed in Uria-Tellaetxe and Carlsaw (2014) applied smoothing to the CBPF values to avoid individual points having excessive impact on the surface prediction. The rationale for smoothing is presented in Carlsaw (2015). In this study, smoothing was applied to the simple CBPFs. However, due to the nature of $\triangle \mathrm{CBPFs}$ (negative to positive), smoothed surfaces did not properly depict the calculated results. Therefore, smoothing was not applied to $\triangle \mathrm{CBPFs}$. In addition, $\triangle \mathrm{CBPFs}$ were computed only if there were at least 4 observations available for both periods.

\section{RESULTS AND DISCUSSION}

The two periods ( $\tau_{1}$ and $\tau_{2}$ ) to be compared in the differential probability functions should be chosen based on known changes in local and regional emissions. However, while the selection of relatively short periods may result in a high temporal resolution, a short time interval also decreases the number of data values and lowers the reliability of $\triangle \mathrm{CBPF}$ and $\triangle \mathrm{PSCF}$ values.

From 2005 to 2016, regional and local emissions have changed significantly (Emami et al., 2018). Vehicle emissions have been significantly reduced (Mariq, 2007; Bishop and Stedman, 2008; Bishop et al., 2012; McDonald et al., 2013; May et al., 2014) with improved emissions controls and cleaner fuels. In 2007, new heavy-duty diesel trucks were required to have particulate filters. $\mathrm{NO}_{\mathrm{x}}$ controls were added in 2010. However, credit flexibilities have allowed the sale of engines with $\mathrm{NO}_{\mathrm{x}}$ emissions greater than the 2010 limit $\left(0.2 \mathrm{~g} \mathrm{bhp}-\mathrm{hr}^{-1}\right)$ through model year 2014 . The light-duty vehicle $(<6,000$ lbs gross weight $)$ Tier 2 emissions program (extended to vehicles up to $10,000 \mathrm{lbs}$ ) required an average sulfur standard of $30 \mathrm{ppm}$ (from 120 ppm) with a sulfur cap of $80 \mathrm{ppm}$ (from $300 \mathrm{ppm}$ ) phasedin from 2004 to 2009. On-road diesel fuel sulfur content dropped from $<500 \mathrm{ppm}$ to ultralow sulfur diesel fuel (ULSD; <15 ppm) in 2006. ULSD fuels were subsequently 
required for non-road vehicles by 2010 and for locomotives and marine vessels by 2014 . Additionally, all distilled oil sold in NYS for any purpose (including building heating) were required to be ULS after July 1, 2012. The implemented regulations and associated technological improvements resulted in a sharp decrease of $\mathrm{NO}_{\mathrm{x}}(-52 \%), \mathrm{SO}_{2}(-85 \%)$, and $\mathrm{CO}(-45 \%)$ in NYS between 2005 and 2016 . These reductions were mostly associated with the decrease in the emissions from highway and off-highway vehicles and fuel combustion for electric power generation (Emami et al., 2018; Masiol et al., 2018; Squizzato et al., 2018).

Local changes also occurred in Rochester, including the 2008 shutdown of a $260 \mathrm{MW}$ coal-fired power plant ( $\sim 15 \mathrm{~km}$ NNW of sampling site, noted as RG \& E in Fig. S1), a major source of $\mathrm{SO}_{2}$ and ultrafine particles (Kasumba et al., 2009; Wang et al., 2011b, b), and decreased emissions from a coal-fired cogeneration plant $(\sim 8.5 \mathrm{~km} \mathrm{NW})$. The monitoring site is adjacent to a mainline railroad and several interstate highways so the changes in on-road and non-road fuel sulfur content between 2006 and 2014 were expected to be significant.

There were also substantial changes in major upwind sources such as electric generating stations driven both by regulatory policies and economics. These changes are discussed in detail by Emami et al. (2018) and Squizzato et al. (2018). Although several major efforts by the U.S. Environmental Protection Agency (Clean Air Interstate Rule and Cross-State Air Pollution Rule) were voided by the courts, many utilities implemented controls. There were also reductions because of legal actions such as the consent decree between American Electric Power and the U.S. EPA. Ontario moved to eliminate all fossil fuel combustion for electricity generation that was completed in 2014. Thus, significant reductions in sulfate and nitrate have been observed in Rochester (Emami et al., 2018) and across NYS (Squizzato et al., 2018).

Four 3-year intervals $\left(\tau_{1}=2005\right.$ to $2007, \tau_{2}=2008$ to $2010, \tau_{3}=2011$ to 2013 , and $\tau_{4}=2014$ to 2016) were defined. These periods roughly represent time intervals in which important changes in emissions occurred with many beginning near the end of $\tau_{1}$ and extending through $\tau_{3}$.

\section{CBPFs}

Individual CBPF plots calculated for the each 3-year period are provided in Figs. S3-S8. The plot surfaces were smoothed (Carslaw, 2015); wind speed/wind direction bins with less than 4 observations are omitted (grey surfaces). For most pollutants, it is possible to see changes in the conditional probabilities from one 3 -year period to the next when all of the plots use the same criterion value across the entire period. The highest conditional probabilities for most variables were found for low/moderate westerly wind regimes with probability peaking toward the $\mathrm{SW}\left(\mathrm{PM}_{2.5}\right.$, $\mathrm{BC}, \mathrm{PNC}_{50-100}, \mathrm{PNC}_{100-500}, \mathrm{CO}, \mathrm{NO}, \mathrm{NO}_{2}, \mathrm{NO}_{\mathrm{y}}, \mathrm{OC}_{\mathrm{pri}}$, $\mathrm{OC}_{\mathrm{sec}}$, sulfate, ammonium). Most pollutants are emitted by vehicular traffic (both exhaust and resuspension) and the CBPFs point toward the I-490 and I-590 highways suggesting that local road emissions dominated other local sources. However, a railway is also adjacent to the south and west of the site. Therefore, the contribution of dieselpowered rail engine emissions must be considered.

Biomass burning (BB) accounts for up to $30 \%$ of Rochester's winter $\mathrm{PM}_{2.5}$ mass (Wang et al., 2011a). BB tracers (DC and $\mathrm{K}^{+}$) (Andreae and Merlet, 2001; Koppmann et al., 2005) showed CBPFs similar to the other pollutants, but also high probabilities toward southeasterly suburban areas (Figs. S3 and S8, respectively). BB from heating, cooking (wood-fired pizza), or recreational purposes is the likely local source. The probabilities for $\mathrm{PNC}_{11-50}$ (Fig. S4) are similar to the other pollutants. However, high probabilities extend into the NW quadrant, i.e., toward the two power plants (Fig. S1). The effect of local emissions is evident for $\mathrm{SO}_{2}$ (Fig. S6), showing two potential source locations, i.e., traffic (SW) and power plants (NW) in the first two periods, then only power plants. This result well depicts the drop of traffic emissions due to the application of stringent rules for fuel sulfur content. Ozone decreases with wind speed (lower probability under calm wind regimes, Fig. S6) suggesting a regional rather than local origin give the low probability values. Titration with locally emitted NO for low wind speeds may reduce the local values by depleting ozone on a timescale of minutes.

Nitrate exhibits increased probabilities for the SW and ESE sectors (Fig. S7). Particulate nitrate originates from gaseous nitric acid and ammonia. Rapid oxidation of $\mathrm{NO}_{2}$ emitted by vehicles on the major adjacent roadways and by the railroad engines would be one contributor to nitrate. Cars as well as residences to the southwest would provide the ammonia. However, ammonia transported from several large sewage treatment plants along the Lake Ontario shore (north and northeast of the site) may also result in increased formation of particulate nitrate.

\section{Differential CBPFs}

The results of the $\triangle \mathrm{CBPFs}$ between the first and last periods $\left(2005 / 2007\right.$ and $\left.2014 / 2016, \Delta \mathrm{CBPF}_{\max }\right)$ are shown in Figs. 1-2. Figs. S9-S14 show the incremental $\triangle \mathrm{CBPFs}$ for each pair of consecutive periods, namely $\triangle \mathrm{CBPF} 1$ (2008/2010-2005/2007), $\triangle$ CBPF2 (2011/2013-2008/2010), and $\triangle C B P F 3(2014 / 2016-2011 / 2013)$. Negative values indicate sectors where the probability of being a local source decreased. This region around the origin in these plots presents results for samples with low wind speeds and thus, poorly defined wind directions. Thus, the probabilities are very similar across the multiple periods and their differences are typically zero or very small. The probability changes were moderately low for most species, and thus, no smoothing was performed on the plot surfaces.

Particulate variables prevailingly linked to primary road emissions $\left(\mathrm{PM}_{2.5}, \mathrm{BC}, \mathrm{PNC}>50 \mathrm{~nm}, \mathrm{OC}_{\text {pri }}\right)$ show moderate $(|0.3|<$ differential probability $<|0.5|)$ to high $(>|0.5|)$ $\triangle \mathrm{CBPF}_{\max }$ decreases from the southern sectors, reflecting changes in highway and railway emissions. The incremental $\triangle$ CBPFs (Figs. S9-S10) for these pollutants suggest the effects of mitigation strategies for mobile emissions in North America, showing the largest declines in the first two periods and, then, lower changes during $\triangle \mathrm{CBPF} 3$. These changes reflect reduction in the sulfur content of 


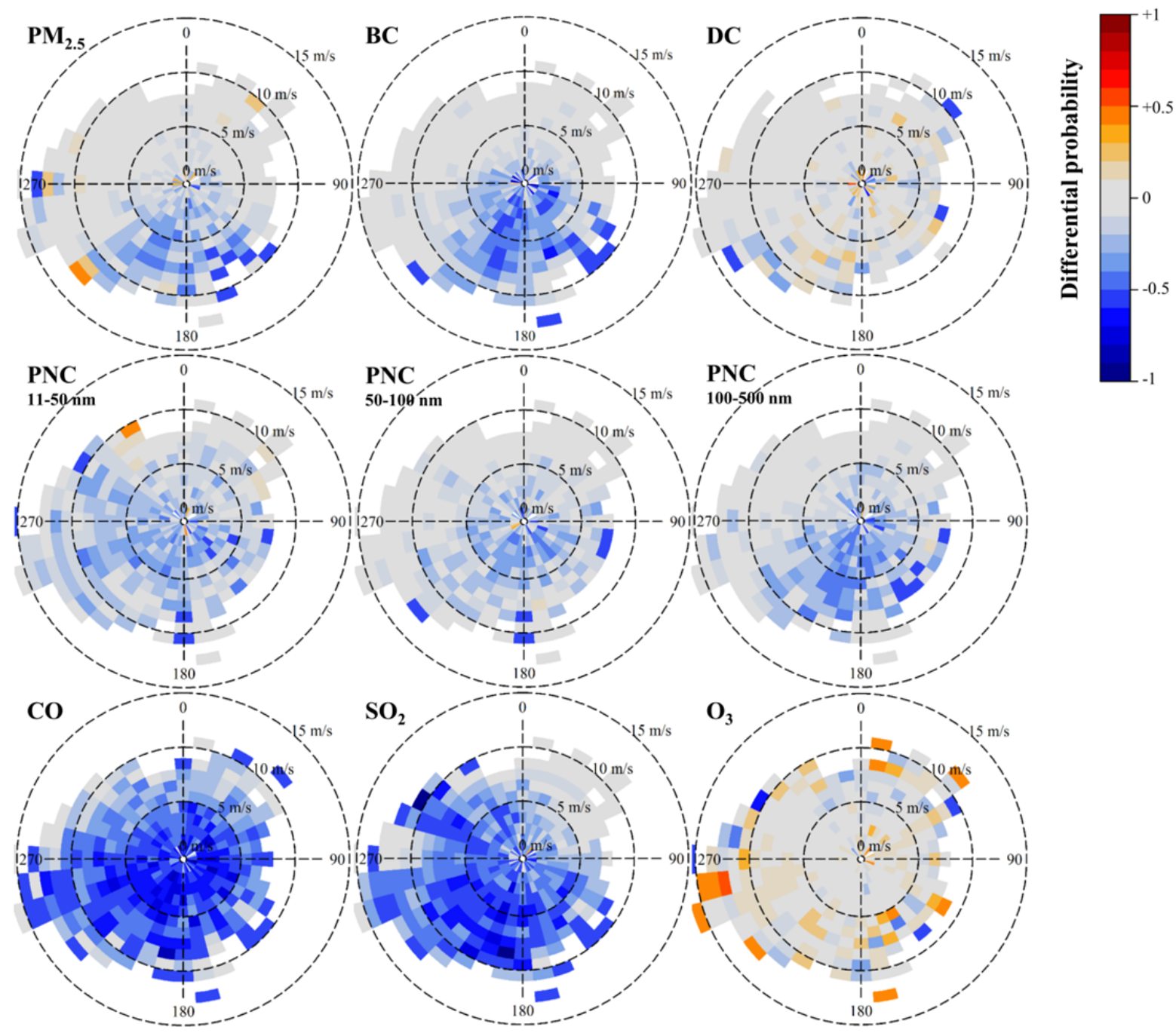

Fig. 1. Results of the differential CBPF between 2005/2007 and 2014/2016 for "FRM-like" $\mathrm{PM}_{2.5}$ (TEOM corrected), aethalometer and SMPS data over the three selected size ranges.

on-road and nonroad diesel fuels and the increasing impact of new heavy-duty diesel vehicles with catalytic regenerative traps that were required after July 1, 2007. Secondary inorganic aerosol (SIA) species exhibited a similar pattern reflecting reduced emissions from road and rail transport. However, nitrate showed increasing probabilities during $\triangle \mathrm{CBPF} 3$. The formation of ammonium sulfate is favored with respect to ammonium nitrate (Seinfeld and Pandis, 2016), but the strong decline in sulfate concentrations in the last decade (Emami et al., 2018) has made more ammonium available to be neutralized by nitrate and, thus, has likely driven the increases seen for $\triangle \mathrm{CBPF} 3$.

$\mathrm{OC}_{\mathrm{sec}}$ exhibited higher $\triangle \mathrm{CBPF}_{\max }$ values toward the southern sectors mostly resulting from the strong incremental effect during $\triangle \mathrm{CBPF} 3$ (Fig. S13). BB tracers $\left(\mathrm{DC}, \mathrm{K}^{+}\right.$) showed low and noisy $\triangle \mathrm{CBPF}_{\max }$ with an overall drop of probabilities in $\triangle \mathrm{CBPF} 2$ and an increase in $\triangle \mathrm{CBPF}$. The increase of $\mathrm{OC}_{\mathrm{sec}}$ in recent years may be in part due to the reductions in $\mathrm{NO}_{\mathrm{x}}$ and $\mathrm{SO}_{x}$ emissions that would permit more oxidation of organic vapors. The rates of reaction of the inorganic species with $\mathrm{OH}$ are substantially higher than with organic compounds and thus, their decreased concentrations could lead to greater SOA formation. BB emissions provide both SOA precursors as well as directly emitted oxidized primary carbon during the smoldering phase.

$\mathrm{CO}$, another tracer of mobile road emissions, experienced high decreases for all wind directions mostly during $\triangle$ CBPF2 (Fig. S11), while no changes were found in $\triangle \mathrm{CBPF} 3$. The absence of directionality may indicate changes in local $\mathrm{CO}$ emissions from diffuse sources, such as domestic heating. However, the $\triangle \mathrm{CBPF}_{\max }$ and $\triangle \mathrm{CBPF} 2$ are probably biased by the change of monitors near the end of 2010 (lower limit of detection and higher sensitivity; Table S1).

$\mathrm{SO}_{2}$ exhibited moderate to high decreases in the southeastern and both western quadrants, indicating an overall decline in concentrations for the major local sources (Fig. 1). However, larger incremental changes were observed in the first two periods (Fig. S12). The highest negative differential probabilities for $\triangle \mathrm{CBPF} 1$ were found toward NW reflecting the shutdown of the coal-fired power plant in 2008. Probability decreases toward SW were dominant 


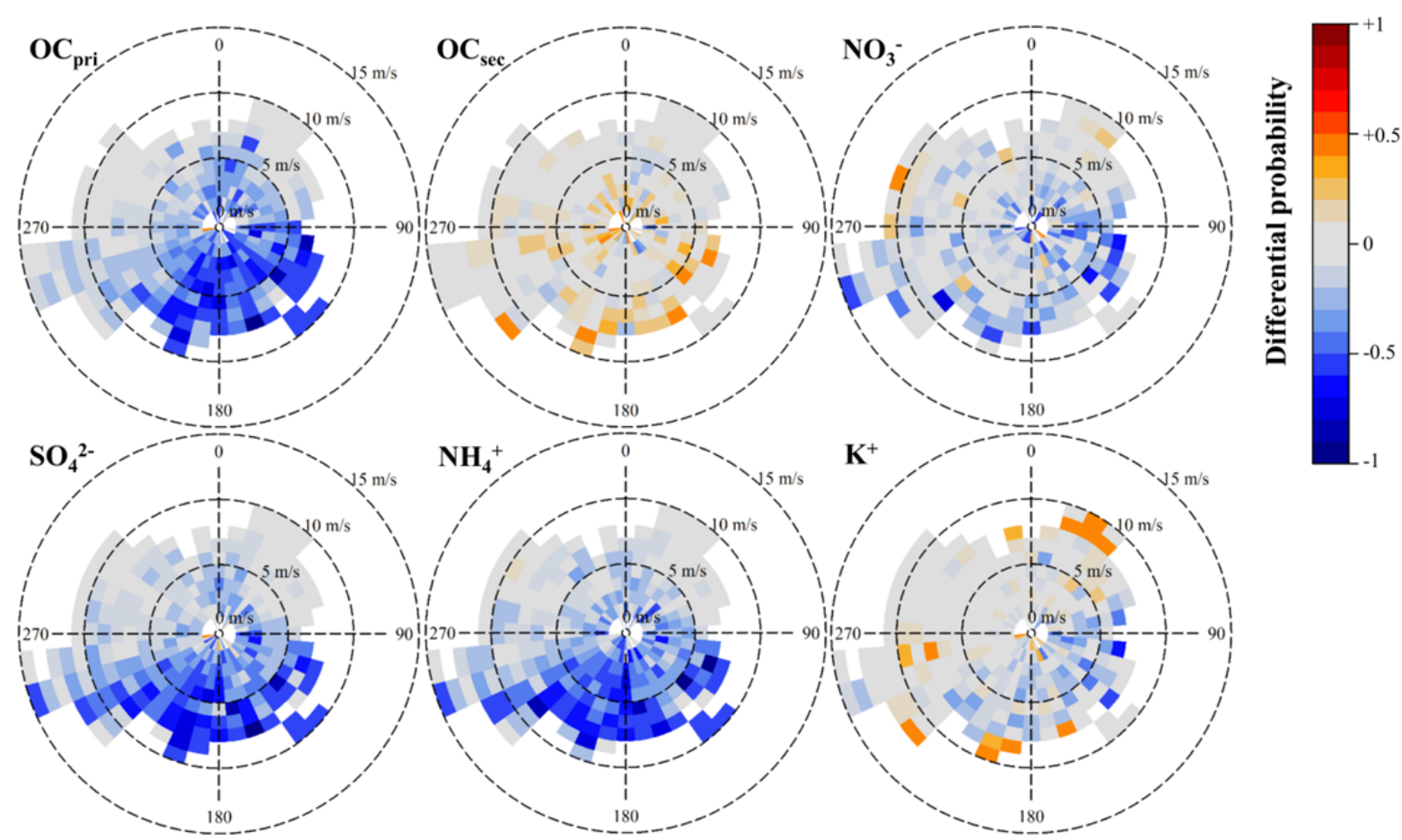

Fig. 2. Results of the differential CBPF between 2005/2007 and 2014/2016 for $\mathrm{PM}_{2.5}$-bound major species.

in $\triangle \mathrm{CBPF} 2$ likely reflecting the local effect of the reduction in sulfur content in non-road rail fuel. The increase to the northwest likely reflects some of the rebound from the 2007-2009 recession and related increased emissions from the cogeneration plant. $\triangle \mathrm{CBPF} 3$ shows much lower decreases only toward the cogeneration plant.

Ozone showed generally low but generally positive $\triangle \mathrm{CBPF}_{\max }$ without any clear directionality. Winter ozone has been increasing in Rochester with the decreases in $\mathrm{NO}_{\mathrm{x}}$ (Emami et al., 2018). Period-to-period incremental changes (Fig. S12) show increases when wind speeds were greater than $5 \mathrm{~m} \mathrm{~s}^{-1}$ suggesting transport of regional air masses to Rochester contributing to local ozone. Nitrogen oxides were only measured beginning at the end of 2010 so there is generally insufficient data to observe clear patterns, except for NO that would only be affected by local sources and showed moderate decreases in all directions.

\section{PSCFS}

Figs. S15-S17 show single PSCFs. For completeness, PSCFs are reported for all the variables except for the particle number concentrations of particles with diameters below $100 \mathrm{~nm}$. However, the overall consistency of PSCFs for highly reactive species (nitrogen oxides, $\mathrm{SO}_{2}$ ) is likely biased by the known relationships between air parcel trajectories and local wind regimes. Generally, most variables exhibited higher probabilities for air mass pathways over the Ohio River Valley $\left(\mathrm{PM}_{2.5}, \mathrm{BC}, \mathrm{PNC}_{100-500}, \mathrm{CO}, \mathrm{OC}_{\mathrm{pri}}\right.$, $\mathrm{OC}_{\mathrm{sec}}$, and sulfate) and moderate probabilities extending northwesterly (central part of Canada). Nitrate presents similar patterns, but higher probability toward the northwest suggesting the role of colder temperatures that accompany northwestern flow into the area. Consequently, ammonium has a mixed behavior relative to nitrate and sulfate. The two BB tracers show different patterns. DC shows higher probability toward the northwest (similar to nitrate), while $\mathrm{K}^{+}$is stronger from the southeastern U.S., particularly the Gulf and southeast coasts. It is unclear why this difference in spatial patterns occurred.

Apart from combustion processes, $\mathrm{CO}$ is also generated by photochemical oxidation of methane and non-methane hydrocarbons. Although $\mathrm{CO}$ has a 30-90 day lifetime in the troposphere (Seinfeld and Pandis, 2016), PSCFs only reveal potential source areas extended over all the continent in 2005/2007 and no patterns afterward; thus, local emissions likely represent its dominant source in Rochester.

\section{Differential PSCFs}

The results of the $\triangle \mathrm{PSCF}$ between the first and last period $\left(\triangle \mathrm{PSCF}_{\max }\right)$ are presented in Figs. 3-4. Figs. S18S20 show incremental $\triangle$ PSCF1 (2008/2010-2005/2007), $\triangle$ PSCF2 (2011/2013-2008/2010), and $\triangle$ PSCF3 (2014/20162011/2013). Generally, most variables $\left(\mathrm{PM}_{2.5}, \mathrm{BC}, \mathrm{CO}, \mathrm{SO}_{2}\right.$, $\mathrm{OC}_{\text {pri }}$, nitrate, sulfate, and ammonium) showed moderate to large decreases in $\triangle \mathrm{PSCF}_{\max }$ spanning the eastern continental U.S. and reflecting the implementation of national scale mitigation measures. However, incremental $\triangle \mathrm{PSCFs}$ showed different temporal sequences of changes. Sulfate exhibited almost constant negative differential probabilities during the entire study period, while $\mathrm{PM}_{2.5}, \mathrm{BC}$, and $\mathrm{OC}_{\text {pri }}$ experienced larger declines for $\triangle \mathrm{PSCF} 1$ and $\triangle \mathrm{PSCF} 3$. Nitrate showed a similar $\triangle P S C F 1$, but increasing differential probabilities were recorded over the Gulf Coast and central U.S. regions during $\triangle \mathrm{PSCF} 2$ possibly reflecting the increased electricity production following the end of the 2008 recession. At the same time, sulfate did not exhibit an 


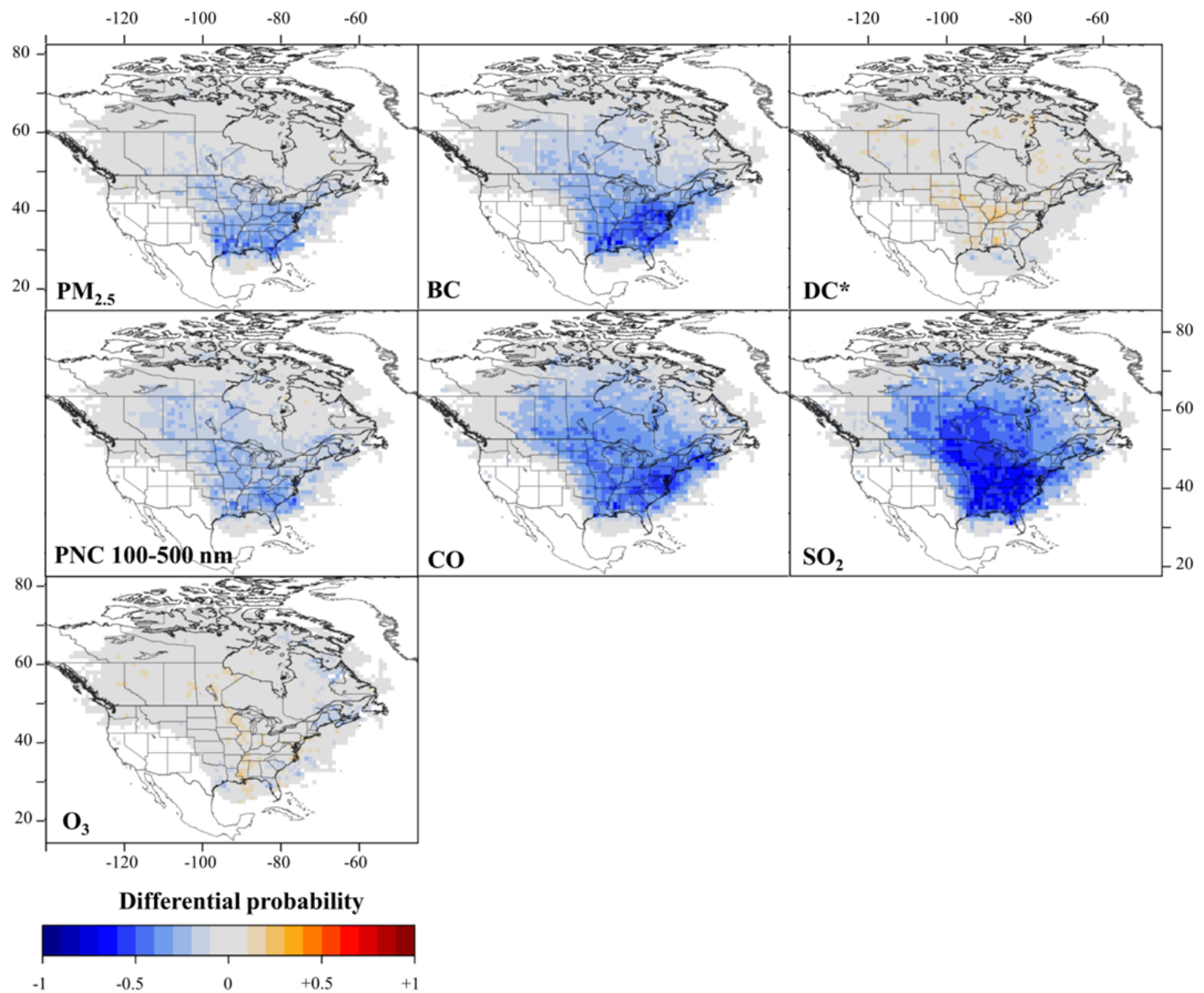

Fig. 3. Results of the differential PSCF between 2005/2007 and 2014/2016 for "FRM-like" $\mathrm{PM}_{2.5}$ (TEOM corrected), aethalometer and SMPS data over the 100-500 nm size range. (*) $\triangle$ PSCF for DC was computed between 2008/2010 and $2014 / 2016$.

increase in probabilities likely due to the shift from coal to cheaper natural gas for power generation, reducing $\mathrm{SO}_{2}$ emissions. Between 2008 and 2009, coal used for power generation started to decline, and natural gas increased both at the state and national level because of changes in the operating costs driven by the relative costs of these fuels (Squizzato et al., 2018). The mirror image of this pattern was observed for $\triangle \mathrm{PSCF} 3$ with net differential probabilities almost zero between 2008/2010 and 2014/2016. Consequently, patterns for ammonium were more similar to those of sulfate than nitrate. This result is expected since at low ambient ammonia concentrations, acidic sulfate neutralization is highly favored over ammonium nitrate formation.

Secondary OC experienced a general increase for $\triangle \mathrm{PSCF}_{\max }$ driven largely by $\triangle \mathrm{PSCF} 3$ (Fig. S20). The increased probabilities extended across North America, probably linked to decreasing $\mathrm{SO}_{2}$ and $\mathrm{NO}_{\mathrm{x}}$ emissions combined with increasing biogenic volatile organic species with the generally increasing summer temperatures. There are increased $\mathrm{OC}_{\mathrm{sec}}$ probability areas in eastern coastal, southern, and midwestern areas of the U.S. and in the boreal forest areas of Canada east of Hudson Bay where wildfires are common (Begum et al., 2005).

DC and ozone maps show very low values but areas of increasing $\triangle \mathrm{PSCF}_{\max }$. The increase in DC suggests additional wood combustion including increasing rates of wildfires in areas to the west of the calculation domain. Increases in ozone primarily reflect higher winter values resulting from $\mathrm{NO}_{\mathrm{x}}$ emissions reductions across the region that are reflected in lower $\mathrm{NO}_{\mathrm{x}}$ concentrations (Emami et al., 2018).

The $\triangle \mathrm{PSCF}$ for $\mathrm{SO}_{2}$ reflect the substantial reductions in emissions over this period. Decreases in PSCF values were observed only during $\triangle \mathrm{PSCF} 1$ and $\triangle \mathrm{PSCF} 2$ when there were shifts in fuel from coal to natural gas because of the change in their relative costs, changes in transport and heating fuel sulfur content and decreased economic activity from 2007 to 2009 and the related need for electricity.

To further examine the utility of the differential PSCF (DPSCF) plots, county-by-county emissions data for $\mathrm{NH}_{3}$, $\mathrm{NO}_{\mathrm{x}}, \mathrm{SO}_{2}$, anthropogenic VOCs, and primary $\mathrm{PM}_{2.5}$ have been retrieved from the U.S. EPA's National Emissions Inventory (NEI) for 2005, 2008, 2011, and 2014 (U.S. EPA, 2018). These values were normalized by the county area to provide an annual emission rate per unit area and 


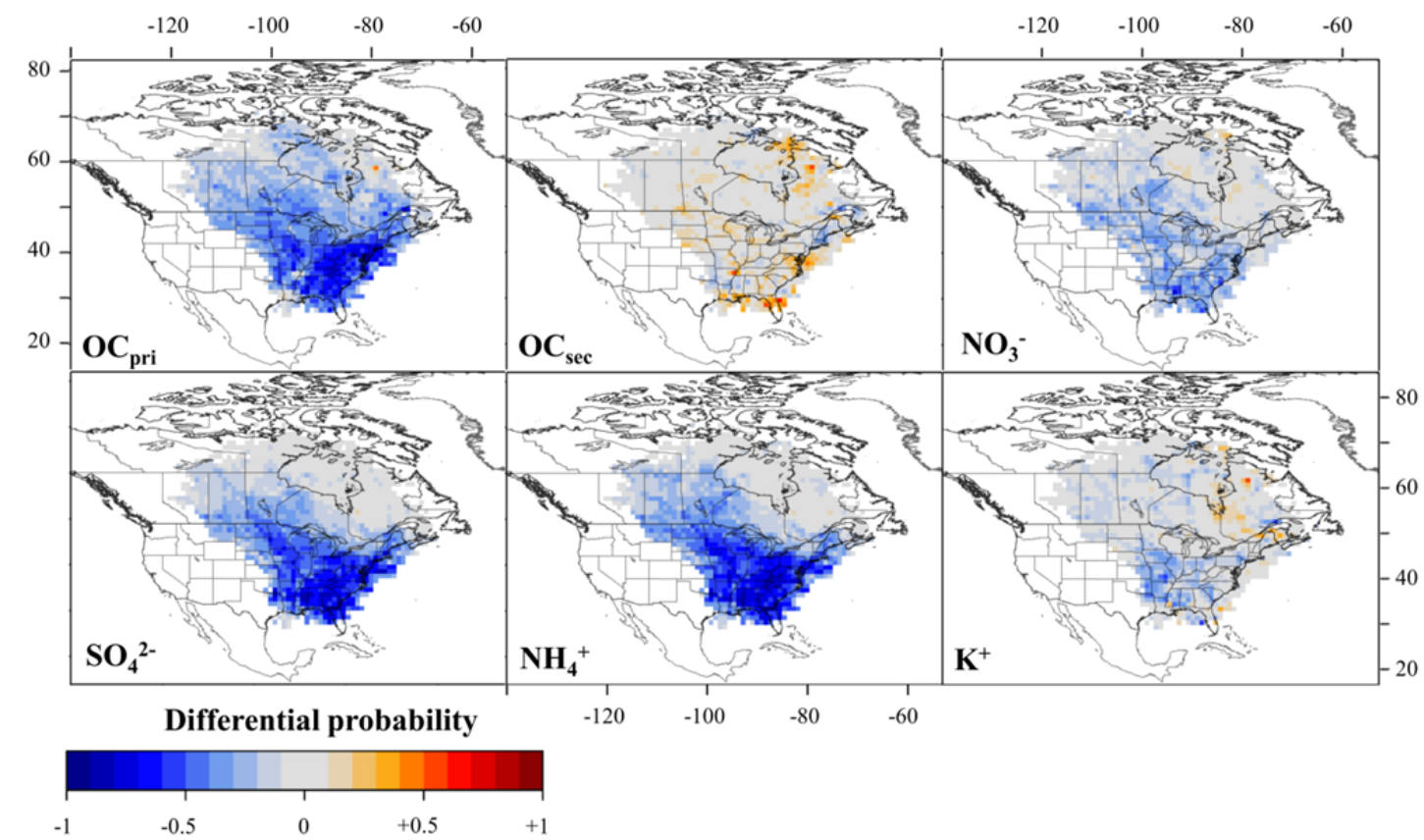

Fig. 4. Results of the differential PSCF between 2005/2007 and 2014/2016 for $\mathrm{PM}_{2.5}$-bound major species.

then aggregated to $1^{\circ}$ latitude by $1^{\circ}$ longitude grid cells to correspond with the PSCF resolution. These plots are shown in Figs. S21-S25. The differences between adjacent periods (2008-2005, 2011-2008, 2014-2011) were calculated as well as the overall difference (2014-2005) for each species. These differential emissions plots are provided in Figs. S26-S30. The U.S. EPA has changed methodology for developing the NEI over time and thus, there is an unknown level of uncertainty in what differences those changes have made relative to the changes in actual emissions. Substantial reductions in $\mathrm{SO}_{2}$ and $\mathrm{NO}_{\mathrm{x}}$ emissions have occurred in the eastern U.S. and generally agree well with the areas in the PSCF with negative differential probabilities. There were both increases and decreases in the ammonia emissions between 2005 and 2014, but the DPSCF map for ammonium only shows strong negative probabilities for the overall period. Since the ammonium is only present in $\mathrm{PM}_{2.5}$ when associated with either sulfate or nitrate, its DPSCF pattern is driven the counter ion to which it is bound.

The $\mathrm{PM}_{2.5}$ map (Fig. 3) shows mostly negative probabilities whereas there were net increases in the central Midwest in primary $\mathrm{PM}_{2.5}$ emissions between 2005 and 2014. However, since $\mathrm{PM}_{2.5}$ is composed mostly of secondary ammonium sulfate, secondary ammonium nitrate, and secondary organic aerosol (SOA), the decreases in these secondary species substantially exceeds the increases in primary PM emissions and the estimated negative probabilities are then what would be expected based on the observed ambient concentration changes (Emami et al., 2018) and the secondary species DPSCF results.

For anthropogenic VOCs, there are both increases and decreases in the estimated emissions over the study period. The increases in more recent years likely reflects the increased economic activity as the economy rebounded from the 2008 recession. The secondary organic aerosol DPSCF map (Fig. 4) shows increased probabilities in these southern areas. However, we cannot relate secondary organic aerosol only to anthropogenic VOCs. Anthropogenic VOCs typically represent about $25 \%$ of the VOC emissions with the remainder being biogenic. The $\mathrm{OC}_{\mathrm{sec}}$ probabilities reflect the increase in oxidant concentrations as reflected by the small upward ozone trend in Rochester reported by Emami et al. (2018). Increased concentrations of $\mathrm{OC}_{\mathrm{sec}}$ were observed in 2014-2016 compared to 2010-2013 across NYS (Zhang et al., 2018). Thus, the decreases in $\mathrm{SO}_{2}$ and $\mathrm{NO}_{\mathrm{x}}$ emissions may have reduced the sink for oxidants like hydroxyl radical and increased the formation of secondary organic aerosol.

\section{Correlations among the Differential Probabilities}

A correlation analysis was performed to qualitatively investigate the relationships among each set of differential probabilities. For the $\triangle \mathrm{CBPF}_{\max }$ results: (i) the differential probabilities of all variables in each wind sector $\Delta \theta$ and wind speed interval $\Delta v$ were merged; (ii) only the $\Delta \theta, \Delta v$ pairs with differential probabilities computed in $\tau_{1}$ and $\tau_{4}$ were retained; and (iii) a Pearson correlation matrix was computed. Similarly, the $\triangle \mathrm{PSCF}_{\max }$ of all variables in each $i, j$ cell were merged; only cells with probabilities in $\tau_{1}$ and $\tau_{4}$ were retained, and correlations were computed. The results were presented as correlograms (Fig. S31). The variables were ordered by applying an agglomerative hierarchical cluster analysis using complete linkage method to group similar variables together using 1-correlation as distance (Murtagh and Legendre, 2014). High correlations identify pairs of variables affected by similar changes of local or regional sources.

There were moderate $(0.4<r<0.6)$ to strong $(r>0.6)$ $\triangle \mathrm{CBPF}_{\max }$ correlations among $\mathrm{CO}, \mathrm{PM}_{2.5}, \mathrm{BC}$, and $\mathrm{PNC}$ in 
the two coarser size ranges, reflecting the negative differential probabilities over the SW-SE sectors (Figs. 1-2), i.e., the drop of local mobile emission sources. The lack of correlation between $\mathrm{SO}_{2}$ and this latter group of pollutants suggests local traffic is not the primary cause of the decrease in $\mathrm{SO}_{2}$ concentrations, i.e., industrial emissions likely dominated the $\mathrm{SO}_{2}$ concentrations in Rochester. Potassium was moderately correlated to PNC $>50 \mathrm{~nm}$ (BB emissions peak around $100 \mathrm{~nm}$ ) (Petterson et al., 2011; Chandrasekaran et al., 2013), but also to $\mathrm{OC}_{\mathrm{sec}}$ and $\mathrm{OC}_{\text {pri }}$. Thus, changes in local $\mathrm{BB}$ emissions may be partially responsible for changes in differential probabilities for primary and secondary OC. Ammonium was strongly correlated with nitrate and sulfate indicating the local SIA production. However, neither sulfate nor nitrate were correlated with other variables indicating that changes in probabilities for SIA species are not linked to local primary emissions.

Results show generally high correlations for $\triangle \mathrm{PSCF}_{\max }$. A large group of variables linked to mobile sources and SIA exhibited moderate to strong inter-correlations. This result depicts the implementation of mitigation measures over North America. Ozone and $\mathrm{OC}_{\mathrm{sec}}$ were not correlated with any other variable. Potassium was moderately correlated with coarser $\mathrm{PNC}, \mathrm{OC}_{\mathrm{pri}}$, ammonium, and nitrate suggesting the influence of wood combustion on primary particles and ammonia concentrations (Hegg et al., 1988).

\section{CONCLUSIONS}

Differential probability functions are useful tools for investigating the changes in emission rates or locations of air pollutants. This study was performed over 12 years of air quality data $(2005 / 2016)$ collected in Rochester, NY. The application of the differential probability functions allowed the identification of the major changes in local and regional emission scenarios that have affected the air quality. The major changes in air pollution due to local changes in emissions were related to (i) the shutdown of a large coal power plant (resulting in a reduction of $\mathrm{SO}_{2}$ ) and (ii) the abatement measures applied to road and off-road traffic (resulting in reduced concentrations of primary pollutants). The concurrent effects of these changes in local emissions also produced a decrease in the number concentration of particles in the nucleation mode $(<50 \mathrm{~nm})$. Changes in regional emission scenarios mostly drove the decreases in secondary aerosol and black carbon concentrations observed in Rochester.

\section{ACKNOWLEDGMENTS}

This work was supported by the New York State Energy Research and Development Authority (NYSERDA) under agreements \#59800 and 59802. Air quality data used in this study are available from the EPA Air Data: Air Quality Data Collected at Outdoor Monitors across the U.S. (https://www.epa.gov/outdoor-air-quality-data). Weather data are available from the NOAA National Climatic Data Center (https://www.ncdc.noaa.gov/data-access). NCEP Reanalysis data are provided by the NOAA/OAR/ESRL
PSD (http://www.esrl.noaa.gov/psd/).

The authors gratefully acknowledge: (i) U.S. EPA and NYS DEC for the CSN data and for hosting and maintaining our SMPS operational at DEC site; (ii) NOAA for the weather and Reanalysis data; and (iii) the NOAA Air Resources Laboratory (ARL) for the provision of the HYSPLIT transport and dispersion model (http://www.ready.noaa.gov) used in this publication.

\section{SUPPLEMENTARY MATERIAL}

Supplementary data associated with this article can be found in the online version at http://www.aaqr.org.

\section{REFERENCES}

Abdalmogith, S.S. and Harrison, R.M. (2005). The use of trajectory cluster analysis to examine the long-range transport of secondary inorganic aerosol in the UK. Atmos. Environ. 39: 6686-6695.

Ahmed, E., Kim, K.H., Shon, Z.H. and Song, S.K. (2015). Long-term trend of airborne particulate matter in Seoul, Korea from 2004 to 2013. Atmos. Environ. 101: 125133.

Andreae, M.O. and Merlet, P. (2001). Emission of trace gases and aerosols from biomass burning. Global Biogeochem. Cycles 15: 955-966.

Ashbaugh, L., Malm, W. and Sadeh, W. (1985). A residence time probability analysis of sulfur concentrations at Grand Canyon National Park. Atmos. Environ. 19: 1263-1270.

Bae, M.S., Schauer, J.J., Turner, J.R. and Hopke, P.K. (2009). Seasonal variations of elemental carbon in urban aerosols as measured by two common thermal-optical carbon methods. Sci. Total Environ. 407: 5176-5183.

Begum, B.A., Kim, E., Jeong, C.H., Lee, D.W. and Hopke, P.K. (2005). Evaluation of the potential source contribution function using the 2002 Quebec forest fire episode. Atmos. Environ. 39: 3719-3724.

Bishop, G.A. and Stedman, D.H. (2008). A decade of onroad emissions measurements. Environ. Sci. Technol. 42: 551-558.

Bishop, G.A., Schuchmann, B.G., Stedman, D.H. and Lawson, D.R. (2012). Emission changes resulting from the san Pedro bay, California ports truck retirement program. Environ. Sci. Technol. 46: 551-558.

Brankov, E., Rao, S.T. and Porter, P.S. (1998). A trajectoryclustering-correlation methodology for examining the long-range transport of air pollutants. Atmos. Environ. 32: 1525-1534.

Brereton, C.A. and Johnson, M.R. (2012). Identifying sources of fugitive emissions in industrial facilities using trajectory statistical methods. Atmos. Environ. 51: 46-55.

Cabada, J.C., Pandis, S.N., Subramanian, R., Robinson, A. L., Polidori, A. and Turpin, B. (2004). Estimating the secondary organic aerosol contribution to $\mathrm{PM}_{2.5}$ using the EC tracer method. Aerosol Sci. Technol. 38: 140155. 
Cape, J.N., Methven, J. and Hudson, L.E. (2000). The use of trajectory cluster analysis to interpret trace gas measurements at Mace Head, Ireland. Atmos. Environ. 34: 3651-3663.

Carslaw, D.C., Beevers, S.D., Ropkins, K. and Bell, M.C. (2006). Detecting and quantifying aircraft and other onairport contributions to ambient nitrogen oxides in the vicinity of a large international airport. Atmos. Environ. 40: 5424-5434.

Carslaw, D.C. and Beevers, S.D. (2013). Characterising and understanding emission sources using bivariate polar plots and k-means clustering. Environ. Modell. Software 40: 325-329.

Carslaw, D.C. (2015). The openair manual - open-source tools for analysing air pollution data. King's College, London, UK.

Chandrasekaran, S.R., Hopke, P.K., Newtown, M. and Hurlbut, A. (2013). Residential-scale biomass boiler emissions and efficiency characterization for several fuels. Energy Fuels 27: 4840-4849.

Cheng, M.D., Hopke, P.K. and Zeng, Y. (1993). A receptor-oriented methodology for determining source regions of particulate sulfate observed at Dorset, Ontario. J. Geophys. Res. 98: 16839-16849.

Cheng, M.D. and Lin, C.J. (2001). Receptor modeling for smoke of 1998 biomass burning in Central America. $J$. Geophys. Res. 106: 22871-22886.

Chow, J.C., Watson, J.G., Crow, D., Lowenthal, D.H. and Merrifield, T. (2001). Comparison of IMPROVE and NIOSH carbon measurements. Aerosol Sci. Technol. 34: 23-34.

Chow, J.C., Watson, J.G., Chen, L.W.A., Arnott, W.P., Moosmüller, H. and Fung, K. (2004). Equivalence of elemental carbon by thermal/optical reflectance and transmittance with different temperature protocols. Environ. Sci. Technol. 38: 4414-4422.

Chow, J.C., Watson, J.G., Chen, L.W.A., Chang, M.O., Robinson, N.F., Trimble, D. and Kohl, S. (2007). The IMPROVE_A temperature protocol for thermal/optical carbon analysis: Maintaining consistency with a long-term database. J. Air Waste Manage. Assoc. 57: 1014-1023.

Chow, J.C., Watson, J.G., Chen, L.W., Rice, J. and Frank, N.H. (2010). Quantification of $\mathrm{PM}_{2.5}$ organic carbon sampling artifacts in US networks. Atmos. Chem. Phys. 10: 5223-5239.

Colette, A., Granier, C., Hodnebrog, Ø., Jakobs, H., Maurizi, A., Nyiri, A., Bessagnet, B., D'Angiola, A., D'Isidoro, M., Gauss, M., Meleux, F., Memmesheimer, M., Mieville, A., Rouill, L., Russo, F., Solberg, S., Stordal, F. and Tampieri, F. (2011). Air quality trends in Europe over the past decade: A first multi-model assessment. Atmos. Chem. Phys. 11: 11657-11678.

Crippa, P. and Pryor, S.C. (2013). Spatial and temporal scales of new particle formation events in eastern North America. Atmos. Environ. 75: 257-264.

Dallmann, T.R. and Harley, R.A. (2010). Evaluation of mobile source emission trends in the United States. $J$. Geophys. Res. 115: D14.

Day, M.C., Zhang, M. and Pandis, S.N. (2015). Evaluation of the ability of the EC tracer method to estimate secondary organic carbon. Atmos. Environ. 112: $317-$ 325.

Dillner, A.M., Phuah, C.H. and Turner, J.R. (2009). Effects of post-sampling conditions on ambient carbon aerosol filter measurements. Atmos. Environ. 43: 59375943.

Duncan, B.N., Lamsal, L.N., Thompson, A.M., Yoshida, Y., Lu, Z., Streets, D.G., Hurwitz, M.M. and Pickering, K.E. (2016). A space-based, high-resolution view of notable changes in urban $\mathrm{NO}_{\mathrm{x}}$ pollution around the world (2005-2014). J. Geophys. Res. 121: 976-996.

Emami, F., Masiol, M., and Hopke, P.K. (2018). Air pollution at Rochester, NY: Long-term trends and multivariate analysis of upwind $\mathrm{SO}_{2}$ source impacts. Sci. Total Environ. 612: 1506-1515.

Eyring, V., Isaksen, I.S.A., Bernsten, T., Collins, W.D., Corbett, J.J., Endresen, O., Grainger, R.G., Moldanová, J., Schlager, H. and Stevenson, D.S. (2010). Transport impacts on atmosphere and climate: Shipping. Atmos. Environ. 44: 74735-74771.

Felton, H.D. (2005). Modifying 50C TEOM Data to Be More "FRM like" for AQI Reporting Using a Nonlinear correction Based on the Julian Day. Paper presented at the AAAR Meeting, Atlanta, GA, USA.

Fleming, Z.L., Monks, P. and Manning, A.J. (2012). Review: Untangling the influence of air-mass history in interpreting observed atmospheric composition. Atmos. Res. 104-105: 1-39.

Gerard, D. and Lave, L.B. (2005). Implementing technologyforcing policies: The 1970 Clean Air Act Amendments and the introduction of advanced automotive emissions controls in the United States. Technol. Forecast. Soc. Change 72: 761-778.

Grange, S.K., Lewis, A.C. and Carslaw, D.C. (2016). Source apportionment advances using polar plots of bivariate correlation and regression statistics. Atmos. Environ. 145: 128-134.

Guerreiro, C.B., Foltescu, V. and De Leeuw, F. (2014). Air quality status and trends in Europe. Atmos. Environ. 98: 376-384.

Harris, J.M. and Kahl, J.D. (1990). A descriptive atmospheric transport climatology for the Mauna Loa Observatory, using clustered trajectories. J. Geophys. Res. 95: 13651.

Hegg, D.A., Radke, L.F., Hobbs, P.V. and Riggan, P.J. (1988). Ammonia Emissions from Biomass Burning. Geophys. Res. Lett. 15: 225-337.

Henry, R.C., Chang, Y.S. and Spiegelman, C.H. (2002). Locating nearby sources of air pollution by nonparametric regression of atmospheric concentrations on wind direction. Atmos. Environ. 36: 2237-2244.

Hopke, P.K. (2016). Review of receptor modeling methods for source apportionment. J. Air Waste Manage. Assoc. 66: 237-259.

Hsu, Y.K., Holsen, T.M. and Hopke, P.K. (2003). Comparison of hybrid receptor models to locate PCB sources in Chicago. Atmos. Environ. 37: 545-562.

IMO (International Maritime Organization) (2013). 
Marpol Annex VI and NTC 2008 with Guidelines for Implementation 2013 Edition, International Maritime Organization, London, UK.

Jeong, C.H., Hopke, P.K., Chalupa, D. and Utell, M. (2004). Characteristics of nucleation and growth events of ultrafine particles measured in Rochester, NY. Environ. Sci. Technol. 38: 1933-1940.

Kabashnikov, V.P., Chaikovsky, A.P., Kucsera, T.L. and Metelskaya, N.S. (2011). Estimated accuracy of three common trajectory statistical methods. Atmos. Environ. 45: 5425-5430.

Kalnay, E., Kanamitsu, M., Kistler, R., Collins, W., Deaven, D., Gandin, L., Iredell, M., Saha, S., White, G., Woollen, J. and Zhu, Y. (1996). The NCEP/NCAR 40year reanalysis project. Bull. Am. Meteorol. Soc. 77: 437-471.

Kasumba, J., Hopke, P.K., Chalupa, D.C. and Utell, M.J. (2009). Comparison of sources of submicron particle number concentrations measured at two sites in Rochester, NY. Sci. Total Environ. 407: 5071-5084.

Keeler, G.J. (1987). A hybrid approach for source apportionment of atmospheric pollutants in the northeastern United States, The University of Michigan, USA.

Kheirbek, I., Haney, J., Douglas, S., Ito, K., Caputo, S. and Matte, T. (2014). The public health benefits of reducing fine particulate matter through conversion to cleaner heating fuels in New York City. Environ. Sci. Technol. 48: 13573-13582.

Kim, E., Hopke, P.K. and Edgerton, E.S. (2003). Source identification of Atlanta aerosol by positive matrix factorization. J. Air Waste Manage. Assoc. 53: 731-739.

Kim, E. and Hopke, P.K. (2004). Comparison between conditional probability function and nonparametric regression for fine particle source directions. Atmos. Environ. 38: 4667-4673.

Kim, E., Hopke, P.K. and Qin, Y. (2005). Estimation of organic carbon blank values and error structures of the speciation trends network data for source apportionment. $J$. Air Waste Manage. Assoc. 55: 1190-1199.

Kim, E. and Hopke, P.K. (2006). Characterization of fine particle sources in the Great Smoky Mountains area. Sci. Total Environ. 368: 781-794.

Klimont, Z., Smith, S.J. and Cofala, J. (2013). The last decade of global anthropogenic sulfur dioxide: 20002011 emissions. Environ. Res. Lett. 8: 014003.

Koppmann, R., von Czapiewski, K. and Reid, J.S. (2005). A review of biomass burning emissions, Part I: Gaseous emissions of carbon monoxide, methane, volatile organic compounds, and nitrogen containing compounds. Atmos. Chem. Phys. Discuss. 5: 10455-10516.

Lim, H.J. and Turpin, B.J. (2002). Origins of primary and secondary organic aerosol in Atlanta: Results of timeresolved measurements during the Atlanta Supersite Experiment. Environ. Sci. Technol. 36: 4489-4496.

Lupu, A. and Maenhaut, W. (2002). Application and comparison of two statistical trajectory techniques for identification of source regions of atmospheric aerosol species. Atmos. Environ. 36: 5607-5618.
Malm, W.C., Johnson, C.E. and Brechs, J.F. (1986). Application of principal component analysis for purposes of identifying source-receptor relationships. In Receptor methods for source apportionment, Pace, T.G. (Ed.), Air Pollution Control Association, Pittsburgh, PA, pp. 127-148.

Maricq, M.M. (2007). Chemical characterization of particulate emissions from diesel engines: A review. $J$. Aerosol Sci. 38: 1079-1118.

Masiol, M. and Harrison, R.M. (2014). Aircraft engine exhaust emissions and other airport-related contributions to ambient air pollution: A review. Atmos. Environ. 95: 409-455.

Masiol, M. and Harrison, R.M. (2015). Quantification of air quality impacts of London Heathrow Airport (UK) from 2005 to 2012. Atmos. Environ. 116: 308-319.

Masiol, M., Squizzato, S., Formenton, G., Harrison, R.M. and Agostinelli, C. (2017a). Air quality across a European hotspot: Spatial gradients, seasonality, diurnal cycles and trends in the Veneto region, NE Italy. Sci. Total Environ. 576: 210-224.

Masiol, M., Hopke, P.K., Felton, H.D., Frank, B.P., Rattigan, O.V., Wurth, M.J. and LaDuke, G.H. (2017b). Source apportionment of $\mathrm{PM}_{2.5}$ chemically speciated mass and particle number concentrations in New York City. Atmos. Environ. 148: 215-229.

Masiol, M., Squizzato, S., Chalupa, D.C., Utell, M.J., Rich, D.Q. and Hopke, P.K. (2018). Long-term trends in submicron particle concentrations in a metropolitan area of the northeastern United States. Sci. Total Environ. 633: 59-70.

May, A.A., Nguyen, N.T., Presto, A.A., Gordon, T.D., Lipsky, E.M., Karve, M., Gutierrez, A., Robertson, W.H., Zhang, M., Brandow, C. and Chang, O. (2014). Gas-and particle-phase primary emissions from in-use, on-road gasoline and diesel vehicles. Atmos. Environ. 88: 247260.

McDonald, B.C., Gentner, D.R., Goldstein, A.H. and Harley, R.A. (2013). Long-term trends in motor vehicle emissions in US urban areas. Environ. Sci. Technol. 47: 10022-10031.

McMurry, P.H. and Friedlander, S.K. (1979). New particle formation in the presence of an aerosol. Atmos. Environ. 13: 1635-1651.

Murtagh, F. and Legendre, P. (2014). Ward's hierarchical agglomerative clustering method: Which algorithms implement Ward's criterion? J. Classification 31: 274295.

Nopmongcol, U., Jung, J., Kumar, N. and Yarwood, G. (2016). Changes in US background ozone due to global anthropogenic emissions from 1970 to 2020. Atmos. Environ. 140: 446-455.

Parrish, D.D., Singh, H.B., Molina, L. and Madronich, S. (2011). Air quality progress in North American megacities: A review. Atmos. Environ. 45: 7015-7025.

Pekney, N., Davidson, C., Zhou, L. and Hopke, P. (2006). Application of PSCF and CPF to PMF-modeled sources of $\mathrm{PM}_{2.5}$ in Pittsburgh. Aerosol Sci. Technol. 40: 952961. 
Pettersson, E., Boman, C., Westerholm, R., Boström, D. and Nordin, A. (2011). Stove performance and emission characteristics in residential wood $\log$ and pellet combustion, Part 2: Wood stove. Energy Fuels 25: 315323.

Petzold, A., Ogren, J.A., Fiebig, M., Laj, P., Li, S.M., Baltensperger, U., Holzer-Popp, T., Kinne, S., Pappalardo, G., Sugimoto, N., Wehrli, C., Wiedensohler, A. and Zhang, X.Y. (2013). Recommendations for reporting "black carbon measurements". Atmos. Chem. Phys. 13: 8365-8379.

Poirot, R.L., Wishinski, P.R., Hopke, P.K. and Polissar, A.V. (2001). Comparative application of multiple receptor methods to identify aerosol sources in northern Vermont. Environ. Sci. Technol. 35: 4622-4636.

Polissar, A.V., Hopke, P.K. and Harris, J.M. (2001). Source regions for atmospheric aerosol measured at Barrow, Alaska. Environ. Sci. Technol. 35: 4214-4226.

Posner, L.N. and Pandis, S.N. (2015). Sources of ultrafine particles in the Eastern United States. Atmos. Environ. 111: 103-112.

Pouliot, G., Denier van der Gon, H.A.C., Kuenen, J., Zhang, J., Moran, M.D. and Makar, P.A. (2015). Analysis of the emission inventories and model-ready emission datasets of Europe and North America for phase 2 of the AQMEII project. Atmos. Environ. 115: 345-360.

Rolph, G., Stein, A. and Stunder, B. (2017). Real-time Environmental Applications and Display sYstem: READY. Environ. Modell. Software 95: 210-228.

Russell, A.R., Valin, L.C. and Cohen, R.C. (2012). Trends in $\mathrm{OMI} \mathrm{NO}_{2}$ observations over the United States: Effects of emission control technology and the economic recession. Atmos. Chem. Phys. 12: 12197-12209.

Sandradewi, J., Prévôt, A.S., Szidat, S., Perron, N., Alfarra, M.R., Lanz, V.A., Weingartner, E. and Baltensperger, U. (2008). Using aerosol light absorption measurements for the quantitative determination of wood burning and traffic emission contributions to particulate matter. Environ. Sci. Technol. 42: 3316-3323.

Schwab, J.J., Felton, H.D., Rattigan, O.V. and Demerjian, K.L. (2006). New York State urban and rural measurements of continuous $\mathrm{PM}_{2.5}$ mass by FDMS, TEOM, and BAM. J. Air Waste Manage. Assoc. 56: 372-383.

Seibert, P., Kromp-Kolb, H., Baltensperger, U., Jost, D. T., Schwikowski, M., Kasper, A. and Puxbaum, H. (1994). Trajectory analysis of aerosol measurements at high alpine sites," In Transport and transformation of pollutants in the troposphere, Borrell, P.M., Borrell, P., Cvitas, T. and Seiler, W. (Eds.), Academic Publishing, Den Haag, pp. 689-693.

Seinfeld, J.H. and Pandis, S.N. (2016). Atmospheric chemistry and physics: From air pollution to climate change, 3rd Edition. John Wiley and Sons, Hoboken, USA.

Solomon, P.A., Crumpler, D., Flanagan, J.B., Jayanty, R.K.M., Rickman, E.E. and McDade, C.E. (2014). U.S. National $\mathrm{PM}_{2.5}$ Chemical Speciation Monitoring NetworksCSN and IMPROVE: Description of networks. J. Air
Waste Manage. Assoc. 64: 1410-1438.

Squizzato, S., Masiol, M., Innocente, E., Pecorari, E., Rampazzo, G. and Pavoni, B. (2012). A procedure to assess local and long-range transport contributions to $\mathrm{PM}_{2.5}$ and secondary inorganic aerosol. J. Aerosol Sci. 46: 64-76.

Squizzato, S. and Masiol, M. (2015). Application of meteorology-based methods to determine local and external contributions to particulate matter pollution: A case study in Venice (Italy). Atmos. Environ. 119: 6981 .

Squizzato, S., Masiol, M., Rich, D.Q. and Hopke, P.K. (2018). $\mathrm{PM}_{2.5}$ and gaseous pollutants in New York State during 2005-2016: Spatial variability, temporal trends, and economic influences. Atmos. Environ. 183: 209224.

Stein, A.F., Draxler, R.R., Rolph, G.D., Stunder, B.J., Cohen, M.D. and Ngan, F. (2015). NOAA's HYSPLIT atmospheric transport and dispersion modeling system. Bull. Am. Meteorol. Soc. 96: 2059-2077.

Stohl, A. (1996). Trajectory statistics - A new method to establish source-receptor relationships of air pollutants and its application to the transport of particulate sulfate in Europe. Atmos. Environ. 30: 579-587.

Tong, D., Pan, L., Chen, W., Lamsal, L., Lee, P., Tang, T., Kim, H., Kondragunta, S. and Stajner, I. (2016). Impact of the 2008 Global Recession on air quality over the United States: Implications for surface ozone levels from changes in $\mathrm{NO}_{\mathrm{x}}$ emissions. Geophys. Res. Lett. 43: 9280-9288.

Turner, J.R., Hansen, A.D. and Allen, G.A. (2007). Methodologies to compensate for optical saturation and scattering in Aethalometer TM black carbon measurements. Paper presented at the Symposium on Air Quality Measurement Methods and Technology, San Francisco, CA, USA.

Turpin, B.J. and Huntzicker, J.J. (1995). Identification of secondary organic aerosol episodes and quantitation of primary and secondary organic aerosol concentrations during SCAQS. Atmos. Environ. 29: 3527-3544.

Uria-Tellaetxe, I.W. and Carslaw, D.C. (2014). Conditional bivariate probability function for source identification. Environ. Modell. Software 59: 1-9.

U.S. EPA (U.S. Environmental Protection Agency) (2016). Highway and Nonroad, Locomotive, and Marine (NRLM) Diesel Fuel Sulfur Standards, https://nepis. epa.gov/Exe/ZyPDF.cgi?Dockey=P100O9ZH.pdf, Last Access: 19 Oct. 2017.

U.S. EPA (U.S. Environmental Protection Agency) (2018). National Emissions Inventory (NEI), https://www.epa. gov/air-emissions-inventories/national-emissions-invent ory-nei.

Virkkula, A., Mäkelä, T., Hillamo, R., Yli-Tuomi, T., Hirsikko, A., Hämeri, K. and Koponen, I.K. (2007). A simple procedure for correcting loading effects of aethalometer data. J. Air Waste Manage. Assoc. 57: 1214-1222.

Wang, Y., Hopke, P.K., Rattigan, O.V., Xia, X., Chalupa, D.C. and Utell, M.J. (2011a). Characterization of 
residential wood combustion particles using the twowavelength aethalometer. Environ. Sci. Technol. 45: 7387-7393.

Wang, Y., Hopke, P.K., Chalupa, D.C. and Utell, M.J. (2011b). Long-term study of urban ultrafine particles and other pollutants. Atmos. Environ. 45: 7672-7680.

Wang, Y., Hopke, P.K., Xia, X., Rattigan, O.V., Chalupa, D.C. and Utell, M.J. (2012a). Source apportionment of airborne particulate matter using inorganic and organic species as tracers. Atmos. Environ. 55: 525-532.

Wang, Y., Hopke, P.K. and Utell, M.J. (2012b). Urbanscale seasonal and spatial variability of ultrafine particle number concentrations. Water Air Soil Pollut. 223: 2223-2235.

Watson, J.G., Chow, J.C. and Chen, L.W.A. (2005). Summary of organic and elemental carbon/black carbon analysis methods and intercomparisons. Aerosol Air Qual. Res. 5: 65-102.

Watson, J.G., Chow, J.C., Chen, L.W.A. and Frank, N.H. (2009). Methods to assess carbonaceous aerosol sampling artifacts for IMPROVE and other long-term networks. $J$. Air Waste Manage. Assoc. 59: 898-911.

Yu, K.N., Cheung, Y.P., Cheung, T. and Henry, R.C.
(2004). Identifying the impact of large urban airports on local air quality by nonparametric regression. Atmos. Environ. 38: 4501-4507.

Zetterdahl, M., Moldanová, J., Pei, X., Pathak, R.K. and Demirdjian, B. (2016). Impact of the $0.1 \%$ fuel sulfur content limit in SECA on particle and gaseous emissions from marine vessels. Atmos. Environ. 145: 338-345.

Zhang, W., Lin, S., Hopke, P.K., Thurston, S.W., van Wijngaarden, E., Croft, D., Squizzato, S., Masiol, M. and Rich, D.Q. (2018). Triggering of cardiovascular hospital admissions by fine particle concentrations in New York State: Before, during, and after implementation of multiple environmental policies and a recession. Environ. Pollut. 242: 1404-1416.

Zhou, L., Hopke, P.K. and Liu, W. (2004). Comparison of two trajectory based models for locating particle sources for two rural New York sites. Atmos. Environ. 38: 1955-1963.

Received for review, September 28, 2018

Revised, October 26, 2018

Accepted, October 29, 2018 